\title{
Pastoral ministry in a missional age: Towards a practical theological understanding of missional pastoral care
}

\author{
Author: \\ Guillaume H. Smit ${ }^{1}$ \\ Affiliation: \\ ${ }^{1}$ Discipline Group for Old \\ \& New Testament Studies, \\ Stellenbosch University, \\ South Africa \\ Correspondence to \\ Guillaume Smit \\ Email: \\ ghsmit@telkomsa.net \\ Postal address: \\ PO Box 195, Brackenfell 7561, \\ South Africa \\ Dates: \\ Received: 03 Sept. 2014 \\ Accepted: 20 Apr. 2015 \\ Published: 11 June 2015 \\ How to cite this article: \\ Smit, G.H., 2015, 'Pastoral \\ ministry in a missional \\ age: Towards a practical \\ theological understanding \\ of missional pastoral care' \\ Verbum et Ecclesia 36(1), \\ Art. \#1382, 8 pages. \\ http://dx.doi.org/10.4102/ \\ ve.v36i1.1382

\section{Copyright:} \\ (C) 2015. The Authors. \\ Licensee: AOSIS \\ OpenJournals. This work is \\ licensed under the Creative \\ Commons Attribution \\ License.
}

Read online:
This article concerns itself with the development of a missional ecclesiology and the practices that may accept the challenge of conducting pastoral ministry in the context of South African, middleclass congregations adapting to a rapidly changing, post-apartheid environment. Some practical theological perspectives on pastoral counselling are investigated, whilst Narrative Therapy is explored as an emerging theory of deconstruction to enable the facilitating of congregational change towards a missional understanding of church life in local communities. Subsequently, the theological paradigm of missional ecclesiology is investigated before drawing the broad lines of a theory for pastoral ministry within missional ecclesiology.

Intradisciplinary and/or interdisciplinary implications: In this article, a missional base theory is proposed for pastoral counselling, consisting of interdisciplinary insights gained from the fields of Missiology, Practical Theology, Narrative Therapy and Cognitive Behaviour Therapy. The implications of this proposal for the development of a missional pastoral theory focus on the following three aspects:

- re-establishing pastoral identity: exploring Christ

- pastoral development: intentional faith formation

- pastoral ministry: enabling Christ-centred lives.

In such a missional pastoral theory four practices should be operationalised: first of all, a cognitive approach to increasing knowledge of the biblical narrative is necessary. This provides the hermeneutical skills necessary to enable people to internalise the biblical ethics and character traits ascribed to the Christian life. Secondly, a pastoral theory needs to pay close attention to development of emotional intelligence. Thirdly, this should be done in the context of small groups, where the focus falls on the personality development of members. Finally, missional pastoral theory should also include the acquisition of life coaching skills, where leaders can be adequately mentored in their roles as coaches of nonequipped people. In taking the research to a further level of normative reflection, attention should be turned to developing specific areas of pastoral care:

- formal clinical education and subsequent accreditation of pastors (in the South African context pastoral care is not legally recognised as a valid area of psychological therapy) specifically pertaining to Narrative Therapy and cognitive behavioural therapy

- basic counselling skills for non-theologically trained congregational leaders

- qualitative and quantitative research methods

- organisational theory for congregational ministry

- crisis counselling skills for congregation members serving in a community context

- marriage and family therapy

- emotional intelligence as outcome of a spiritual growth cycle

- leadership development and personality assessment

- personal growth by confronting and crossing emotional and cultural boundaries.

\section{Introduction}

To the attentive eye it appears that a common theme threads through literature on psychological and pastoral counselling: people of the 20th and early 21st century - specifically those who live in societies dictated by western-styled logic and reasoning - seem to be searching for meaning, purpose and even hope. It is particularly the growth in psychosocial sciences of compassionate care that forced the church at large to take note of these developments (De Klerk 1978:1). Moreover, there seems to be a deeply embedded conviction that - under the proper conditions some people are capable of helping others come to grips with problems in living: counsellors, psychiatrists, psychologists, social workers and members of the clergy are all expected to help people manage the distressing problems of life (Egan 1990:4). 
Yet an inquisitive and innovative psychiatrist once stated, 'there have been many reports of a growing impatience with psychiatry, with its seeming foreverness, its high cost, its debatable results, and its vague, esoteric terms' (Harris 1973:xv). His bold innovation resulted in the rise and popularity of Transactional Analysis as tool of change to people searching for meaning in life and healing for their brokenness. Although opinions would differ as to the impact and success rate of Transactional Analysis as a transformational tool in psychotherapy (something not offered in this article), the runaway success of Harris's little yellow book - with it being a New York Times Best Seller and all - ushered in the era of popularised self-help psychology, even as his was not the only book to contribute towards this move.

The increasing pace of change and the 'dechurchification' of industrialised countries have also accelerated the growth in the helping professions. Where the local parish in the past served as automatic support network in times of crisis and the pastor cared for the flock by serving as first line of advice and therapy for many people, the exodus from mainline churches across the world (Smit 2011:32-40) altered the way people perceive first avenues of help for matters emotional, therapeutic and even spiritual. Robinson and Wall (2006:3) concluded that we currently live in an era where people pursue all matters spiritual; specifically pertaining to following Jesus, whilst eschewing the church as institution. Adding to this fray, the explosion in knowledge that humanity currently experiences, has fundamentally changed society from skillsbased specialisation to knowledge-based integration (Miller 2004:4-7). For the purposes of this article, the growth of Christianity in economically upcoming societies of the two thirds world and the central role the church is playing in these communities are not taken into account. It reflects the context of the researcher being a pastor in a middleclass suburban congregation of highly skilled people that displays a high degree of uniformity towards western culture and sociology. It also aims to consider the shift from western culture as primarily a Christian society to a post-Christian, missional setting where the Christian tenets of western culture are actively being deconstructed, thus necessitating a theological reconstruction of ministry and mission.

The purpose of this investigation can therefore be described as the search for new theological theories within a developing missional ecclesiology that can contribute to the reconstructing of pastoral ministry in congregational settings as a missional practice. This coincides with an interprative practical theological research cycle as proposed by Heitink (1993:161) as well as Osmer (2008:4). In such a cycle the development of theological theories also has the task of developing theories of praxis that function as constructive expressions of the interplay between tradition (Scripture), context and interpretation.

\section{Practical theological insights into pastoral ministry}

The need for a theological theory that enables practical theological reflection of pastoral ministry to do justice to the 'modern contributions' by the various sciences that study human personality, whilst critically reflecting on it in relation to the theological tradition, was determined early on in the conversation between contemporary social science and theology (Hiltner 1958:7). The notion of Christians caring for each other's well-being, both as spontaneous expressions of mutual love and as formal ministry of the organised church, is borne from the way Christians experience their relationship to God and to other people as inseparable and based on the love commandment presented by Jesus as ultimate ethical goal, as presented in Matthew 22:37-40 (Hiltner 1958:17).

As such pastoral ministry forms an integral part of the theological encyclopedia. Theology has been described as a process where one comes by credible and critical way to a theoretical accountability of the Christian faith (Van Huyssteen 1987:2). It is an ongoing search for the fullness of the truth of God made known in Jesus Christ (Migliori 2004:1). In this process the theological practitioner must have the courage to push the language of his or her faith - including its theological concepts, theories and models - to the extreme boundaries of possible meaning. It presupposes a conceptual transformation where he or she already considered his or her double binding to both the Christian tradition and the expectations of contemporary consciousness in a positivecritical and constructive way.

This brings the challenge of pastoral care in its broadest sense to the surface: how should the church in all her ${ }^{1}$ expressions listen to people in order to understand and interpret the human existence in terms of God's revelation (Louw 1999:7)? This practice of listening as a mutual ministry between the person who - for the moment of the pastoral encounter assumes the role of God's earthly envoy of some sorts strives to understand another in his or her concrete situation, is a exercise that strives to understand oneself and the other in the perspective of the gospel so that they can determine once again why they exist (Bons-Storm 1989:9). Morkel (2012:48) stated that the pastoral encounter is about the relationship between God and humanity and should be understood as a hermeneutics of pastoral care which endeavours to establish an encounter which metaphorically speaking serves as an embodiment of the presence of God. The 'reimagining of God' cannot be reserved to ecclesiological, liturgical or homiletical approaches alone.

Accordingly, it moves pastoral care into the confines of the core task of practical theological interpretation (Osmer 2008:4):

- as descriptive-empirical practice it enables the pastoral counsellor to gather information that will help him or her discern the particular episodes, situations or patterns in the narrative of the counsellee

- as interpretive task it draws on the theories of psychology and other neuroscientific research

1.Throughout this article gender-neutral language is used, with the exception of reference to the church (female) and God (male), which is in accordance with the biblical metaphors of the church as a bride and God as Father. 
- being normative it also enables the counsellor to interpret the stories presented from a hermeneutical perspective, whilst drawing on the biblical narrative to construct ethical norms and paradigms to provide perspective on the existential questions

- and, finally, as pragmatic task pastoral counselling presents integrated strategies of action that will enable the counsellor to aid his or her counsellees in influencing and changing their own situations through cognitive behavioural interventions and emotional-narrative support.

Narrative Therapy, as social scientific approach from a poststructuralist perspective, provides useful critical lenses in developing practical theological models for pastoral ministry (Morkel 2012:28). Some of the lenses that enable the development of appropriate pastoral theories for the reimaging of God include the externalisation of problems, and the reauthoring of the dominant stories in peoples' lives (White \& Epston 1990). It relies heavily on the interpretive method of social scientific research, as reality cannot be known objectively and all-knowing requires an act of interpretation (White \& Epston 1990:4). This enables the facilitation of meaning attributed to events that determine behaviour. As such, Narrative Therapy encourages richer, combined narratives to emerge from disparate descriptions of human experience (Payne 2006:7).

This approach resonates quite well with a generation of people whose cultural world view shifted from rational science to relational perception. These belong-before-theybelieve people are interested in the experiences they share, the bonding they acquire through sharing life together, and the caring support they grant each other through life's suffering and search for meaning. Sweet (1999:187) showed how a literal approach to human connectedness can help the church move beyond the constraints of its perceived separateness from the rest of the world. He argued in favour of an experience economy in which the dominant characteristics are emotion (heightened concern for personal and spiritual well-being) and motility (fast movement and rapid change). It also resonates well with the contributions made by writers from an African perspective, who argued that pastoral care should be seen as a social and community issue where the individual moves from the centre-stage of the caring process to be replaced by the community and network of relationships (Berinyuu 1988:5; Louw 1994:21).

Considering that the church's message is carried by language, she can help provide meaning to the social occurrences of people living a rapidly changing world. As Ricoeur (1991:165) successfully argued, language systems and the structural analysis utilised in unlocking it can be applied to social phenomena as well. Through scientific knowledge as discourse, language replaced knowledge as the end in itself to become the creator of meaning, albeit pragmatically. It is indeed the end of grand metanarratives based on universal transcendent truths (Lyotard 1984:37-38). What now transpires is the freedom of theology from the modernist constraints of over-analysing God and religion and humanity's search for meaning in relation to God - and discover the wholly other presence of God ties our tongues whilst he fills us with passion (Caputo 1997:3).

\section{Towards a missional ecclesiology}

In every age the church has had to listen to God through the Bible to discern a pattern of living the gospel in a way that is appropriate for that age (McKnight 2008:129). This practice of discernment can also be understood as an ongoing conversation around the stories, concepts and language of the witnesses to God in the Bible. It enables us to connect with the people of our own time who are instinctively yearning for a connection to God (Martoia 2007:39). At the centre of this ongoing practice of discernment the church, as common witness to God's mission to this earth through Christ, is called to live life: by being aware of the communion with Christ and with each other Christians - being the church proper - are compelled to give a visible witness together (Bosch 1991:463).

In following the contours of the biblical witness, Christians tell the story of God's actions in human history through their testimony. They testify about God's goodness, a goodness he has made known, revealed and which defines his purposes (Güder 2000:29). Moreover, the Christian faith is intrinsically missional, purposefully called to share in God's actions, otherwise it has no reason for existence (Bosch 1991:8-9). Through the centuries the church demonstrated an innate adaptability to be part of this mission - starting with the leap from Jewish sect to global religion, as recorded in Acts chapter 15, passing through every major paradigm shift in history.

This ability becomes apparent when we also take into account that the Bible itself is a testament to the hermeneutical activities of its writers, taking existing faith traditions - verbal as well as written - and interpreting it for new circumstances (Smit 2006:11). Biblical texts as faith documents were written to preserve religious traditions in times of crisis with the purpose of producing, maintaining and directing the faith of its adherents (Kenney 2000:1). The Bible can also be described as a story of God's faithfulness to creation and to humanity, a story that culminates in the life, death and resurrection of Jesus Christ. It is God's faithfulness that brings Christian faith to life and thus serves as the basis for theological reflection (Osmer 1992:15-17). New Testament scriptures especially show the practice of the early church to interpret Old Testament writings in light of the ministry, death and resurrection of Jesus whilst trying to explain and understand their faith communities' particular circumstances. Scripture does not debate the existence of God, but retells the story of his deeds in the history of humanity through the testimony about God's goodness, a goodness that is made known by God himself, and that defines his purposes (Güder 2000:28-29).

The Christian faith of the early 21st century needs a new theological paradigm that explores the very nature of the church's testimony as shaped by Jesus and his mission in 
the context of a society rapidly changing and adapting to an explosion of technological advances and resultant cultural changes. Gibbs and Coffey (2001:216) provided a schematic description of this new paradigm. To be thoroughly missional, churches must address each of the following four reference points with all the tension that it produces (Figure 1).

Sharing in this critical contextualisation one finds the scriptures of the Judeo-Christian faith in a central focal role. Scripture serves as an ancient mirror to discern possible contributions to our sharing in the mission of God. We have the responsibility to continue the move forward according to and in the freedom of the gospel of Christ, making it our duty to discern and articulate how believers can live up to the gift and responsibility of this gospel in our present situation (Gehring 2004:301). Therefore, the focus of establishing a theological theory of missional pastoral counselling must also include studying the biblical corpus in search of a fuller picture of what being missional implies. After all, the church can be described as a dressing window of God's reign in a specific community ( $\mathrm{Nel}$ 1994:11). In helping people to achieve new hope in the midst of life's hurts and crises, the ministry of pastoral care is the way a community of faith can challenge and nurture the brokenness of the people of this world into a life filled with stories of hope, healing and God's grace. That is letting Scripture be Scripture (Wright 2009:40).

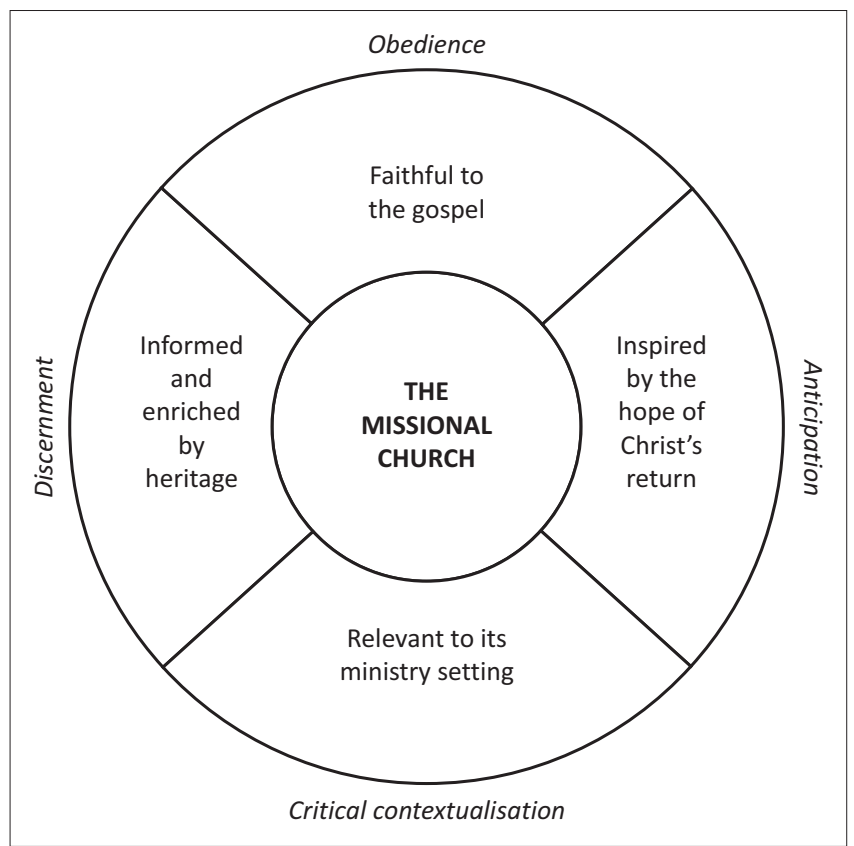

Source: Gibbs, E. \& Coffey, I., 2001, Church next: Quantum changes in Christian ministry, p. 26, Inter-Varsity Press, Leicester

FIGURE 1: Four reference points.

\section{Pastoral ministry from a missional perspective: A practical theological base theory \\ Hermeneutical framing}

It is an ever-demanding challenge to combine the social and narrated worlds of the biblical text in attempts to assert its meaning for contemporary theological theories (O'Day 1995:345). Theological reflection needs to facilitate developments in the ministry practices of the church, which has the task to live the faith (Burger 1999:9-10). In this, Christians participate in the 'liberating mission of Jesus, wagering on a future that verifiable experience seems to belie' (Bosch 1991:519). In a practical theological ecclesiology this participation can be structured as indicated in Table 1 (Smit 1997:178, 2008:167).

An effort to describe the missional purposes necessary to participate in the mission of God was made through investigating the occurrences of the marturia-wordgroup in the gospel of John (Smit 2011). Four missional purposes were identified (Smit 2011:246):

- loving God through Christ

- being open and inviting

- loving one another like Christ

- sharing the ministry of Christ.

Reporting on an empirical study undertaken in 1000 North American congregations and involving 250000 congregation members regarding spiritual growth practices, Hawkins and Parkinson (2011:195) found that members of these faith communities exhibit the following characteristics (Hawkins \& Parkinson 2011:265-273): some people attending church had a basic belief in God, but are unsure about Christ and his role in their lives. Others have made a commitment to trust Christ with their souls' salvation and for eternity, but they are just beginning to learn what it means and what it takes to develop a relationship with him. A third grouping were depending on Christ every day, where they view him as someone who assists them in life and on a daily basis turn to him for help and guidance for the issues they face. A final group of people identified their relationship with Christ as the most important relationship in their entire lives, whilst seeing their lives as fully surrendered to Jesus and his agenda, subordinating everything to his will and his desires.

Incidentally, this demarcation serves as usable framework for the discussion on a missional pastoral theory of church ministry, as it adds confirmation to the hypothesis presented

TABLE 1: Participation structure.

\begin{tabular}{|c|c|c|c|}
\hline Description & Identity & Growth & Service \\
\hline Individual: God-imagery & $\begin{array}{l}\text { A covenant community called together } \\
\text { by the Father }\end{array}$ & $\begin{array}{l}\text { New life through the redemptive work } \\
\text { of Jesus Christ }\end{array}$ & $\begin{array}{l}\text { Empowerment by the dynamic inner work } \\
\text { of the Holy Spirit }\end{array}$ \\
\hline Group: Relational imagery & A life of gratitude in the presence of God & Leadership as gift of the body of Christ & The church as a household \\
\hline Ministry: Missional service & $\begin{array}{l}\text { Leitourgia: worship geared towards the } \\
\text { glorification of the triune god }\end{array}$ & $\begin{array}{l}\text { Koinonia: gift-based ministry aimed at the } \\
\text { edification of the congregation }\end{array}$ & $\begin{array}{l}\text { Marturia: witnessing through one's life } \\
\text { aimed at the expansion of god's new world }\end{array}$ \\
\hline
\end{tabular}

Source: Smit, G., 2008, 'Die ontwikkeling van 'n strategiese gemeentelike ekklesiologie: Op pad na 'n missionerende bedieningspraxis', Acta Theologica 1, 161-175 
in the practical theological ecclesiology described in the previous paragraph. The question that remains is: how should a theological theory of missional pastoral counselling represent this participation in God's mission?

\section{Re-establishing pastoral identity: Exploring Christ}

At first glance, it would seem strange to focus the first missional purpose of a pastoral ministry theory on the exploration of Christ. Yet, to focus on the religious identity of a person - in its different manifestations - is a very crucial starting point for emotional well-being. We were reminded by James Fowler (1981) that people tend to get their religious identity stuck in a stage of synthetic conventional belief, wherein an all-encompassing belief system is adopted. They tend to view life and religion from a legalistic perspective where God is an impersonal Being that gets represented by another human being such as the pastor (Baker 2011). This, according to Fowler, strongly correlates with the psychological stage of adolescence and early adulthood. This belief system is usually a conglomerate of a person's upbringing, his or her involvement or noninvolvement with a church and the religious foundation this laid into his or her life. Smith and Snell (2009:142) reported that emerging adults in North America retained their religions (in which they were brought up) and sometimes soften and even downplay the more subjective parts of their faith whilst entering adulthood. They hold on to the basic tenets of the faith communities presented to them by parents and congregations, thus adding sociological confirmation to what Fowler postulated decades earlier.

A convincing argument can additionally be made for the lasting effects on a person's belief system and emotional health by his or her parents' behaviours during the formation stages of life: it is in the overt or covert behaviours of a person's parents and other family members that rules of behaviour and beliefs are unconsciously established and eventually reenacted (Friel \& Friel 1990:43). These interlinked behavioural beliefs and patterns forms a stronger basis for a person's internalised adult religious system than any amount of Sunday school education. The more dysfunctional a person's childhood development was, the more likely that will result on his or her own dysfunctions, especially as family members are unable, or unwilling, to tackle their difficulties overtly (Burnham 1986:35). From this it can be concluded that the same systemic implications for a person's religious system could exist, thus necessitating the inclusion of some form of family-systemic approach in the theological reconstruction of people's God-imagery.

What practices would be necessary to establish missional pastoral theory in congregational communities? Hamman (2005:25) spoke of it as a sacred heart ministry, where a sacred heart leader is someone who has personal experience in mourning and is not afraid to walk towards his or her losses. Pastoral leaders and their congregations need to do grief work, he argued (p. 34). They do this by creating holding environments, where relationships are created that can withstand strain and anxiety (Hamman 2005:39). As this aspect of the missional pastoral theory encompasses a person's religious identity, the pastoral role should be prophetic, in the sense that it serves as harbinger of the hope provided by knowing Christ. Not only should the narrative of the liturgy and sermon be cast in the metaphors of God's kingdom and the new life it provides, openness and an inviting atmosphere should intentionally permeate the relational networks created amongst the members of the community.

\section{Pastoral development: Intentional faith formation}

One of the confessional creeds of the faith tradition I am part of, the Heidelberg Catechism, described faith development as a result of true conversion and the gratitude that accompanies redemption through Christ. Genuine repentance is, in its turn, described as the dying away of the old self and the rising-to-life of the new (Ursinus 1563). Whilst the dying away of the old self is attested to a person's genuine sorrow for his or her own sin and his or her intentional turning away from such a lifestyle, the rising-to-life of the new self was understood as a joy in God through Christ and the commitment ('a love and delight') to live according to the will of God by doing every kind of good work. The framework for these good works is then presented through observing the commandments - contained in the Decalogue, as found in Exodus 20 and Deuteronomy 6, and through prayer - specifically the Lord's Prayer as found in Matthew 6 and Luke 11. The pastoral implication of this approach was to view pastoral work through the lenses of church discipline - by means of admonishment and conversion - as well as changing the sinner through proclamation and forgiveness (Louw 1999:44). Based on the doctrine of the total depravity of humanity - derived from Augustine (Hanko, Hoeksema \& Van Baren 1976), it assumes that pastoral care is in essence an administering of the word with the aid of the sacraments and of church discipline to counteract spiritual decline.

Yet, the explosion in knowledge observed over the past decades is starting to challenge this framework of handling human need as the consequence of sin. Developments in biblical exegesis - such as narrative criticism - opened up the possibility of alternative interpretations of biblical texts that were read legalistically, or within the fall-redemptionconversion scheme of Bible reading. It furthermore forms part of the reformed tradition to connect God's Word with every new circumstance (Niemandt 2007:47). One must take into account that this legalistic view of human suffering is not reserved for reformed theology only. Willard (2006:13), writing from a nonreformed perspective, posed the question why it is necessary to ask for more than believing in Jesus' forgiveness of sins and the consequential understanding of faith from a legal perspective. Without a focus of apprenticing oneself in Kingdom living, he argued (Willard 2006:14), we remain locked in defeat so far as our moral intentions are concerned. 
Due to the existence of different and often opposing thought and scientific paradigms (Kuhn 1996:122) and established through a postmodern hermeneutic that argues against the existence of any single grand metanarrative that can explain everything (Wright 2006:45), one person's absolute truth is another one's area of scepticism. An alternative pastoral approach to human suffering, which can produce comfort, care and aid (Louw 1999:34), is needed even if the 'orthodox view' of humanity's fall as cause for all suffering is still recognised as one of the multiple contexts of reading the gospel (Franks 1998:342). After all, the Christian gospel insists that the transformation of the human personality is possible (Ortberg 1997:8), and it is not only a practice of turning away from sin, however sin is defined.

Hawkins and Parkinson (2011:668-948) discovered that the biggest group of their survey, those people who were involved in the process of spiritual formation and growth, only started growing personally when they took steps to increase their knowledge of Scripture, became part of small groups that fostered mutual care, and increased their involvement in church activities. Yet they reported the increase in their love of Christ and subsequent devotion to him. Furthermore, it was found that churches' coaching role was crucial to these ends.

In a missional pastoral theory three practices should be operationalised: first of all, a cognitive approach to increasing a basic foundation of knowledge pertaining to the biblical narrative is necessary. Although this overlaps other areas of Practical Theology, it is evident that the providing of the hermeneutical skills necessary to enable people to internalise the biblical ethics and character traits ascribed to the Christian life falls under the auspices of a pastoral theory. Secondly, and flowing from the first practice, a pastoral theory needs close attention to the enabling and development of emotional intelligence. Emotional intelligence (EI) refers to the ability to perceive, control and evaluate emotions (Cherry 2012). Thirdly, this should be done in the context of small groups, where the focus not only falls on increased Bible knowledge, but also - through the coaching of the leaders - on the personality development of members.

\section{Pastoral ministry: Enabling Christ-centred lives}

Disciples of Jesus strive and learn to be like him (Willard 2006:24-30). This process starts with knowledge, continues to changing attitudes and ends with changed behavioural patterns in every aspect of a person's life. Our emotional well-being and maturity forms an integral part of this goal as ultimate end of missional living. As stated by Scazzero and Bird (2003:19), the lack of integrating emotional maturity by focusing on love into the process of discipleship results in missing God's point with his mission (love) completely.

To achieve this, missional pastoral ministry needs a new paradigm of leadership, where listening is more crucial than acting. Through this narrative relationship pastoral leadership let the future shine through in support of the present and despite the past (Sweet 2004:11). In this sense, disciples of Christ are called to be followers and leader simultaneously. It involves skills necessary to understand the mission and to articulate it in such a way that it is embodied in a tangible way by changing behaviours as well as inspiring others to follow in the same footsteps. Yet, to create balance between being a follower-listener and a leader-enabler takes a large measure of skill and personal maturity (Hackman 2002:90). If it is challenging in an organisational setting, even more so in a volunteer environment that depends on the goodwill and buy-in of people who do not obtain their livelihood from the practice.

Missional pastoral leadership, then, is the process where (Keifert 2007:86):

- leaders lead from spiritual discernment by daily engaging in faith forming practices

- listening and communicating with each other and the members of the community in the context of the biblical narrative

- confirming an atmosphere of risk

- is sold out to the challenges of a missional era

- have acquired the skills and competencies necessary to lead missional pastoral teams.

The second practice necessary to enable Christ-centred lives is the practice of helping people to cross boundaries. Boundaries as missional pastoral category is understood as the cultural norms, borders or belief systems that inhibit personal growth, self-sacrifice and the ability to associate with the plight of the voiceless fringe members of society. As I am writing from a white, middleclass South African perspective serving a congregation of primarily homogeneous members, this pastoral practice is particularly urgent. Borrowing from Desmond Tutu, Nell (2011:5) argued for the need of such a process as Sunday morning is still the most segregated hour in South Africa and racial reconciliation the unfinished business for theology in our country. Building on Turner's theory of social drama to explain the intentional effort of facilitating the healing of memories through workshops between white South Africans and black victims of the apartheid era, Nell (2011:2) spoke about the ability or inability to identify with the audience (which Turner described as the other group in the social drama): what seems obvious to one group is an obstacle for others, he explained. According to Turner (1986:196), a social drama is a spontaneous unit of social process, or an eruption from the level surface of ongoing social life with its customs making for regular sequences of behaviour. In this, the act of providing missional pastoral guidance addresses the innate urge to protect the regular sequences of behaviour by fencing off anybody who acts, believes and looks differently. In the South African context it is most evident through the dying of white congregations in areas where new-comers abound, yet they do not speak Afrikaans, are white or even reformed. Congregations choose to amalgamate with neighbouring churches and eventually withdraw from the area rather than crossing the boundaries inhibiting them to minister to the people amongst them. 
To achieve the facilitation of such a boundary crossing, a participatory pastoral praxis is suggested. A participatory pastoral praxis is a movement away from viewing the pastor as the one with superior knowledge about God to an approach which involves compassionate participation with people in processes involving meaning-making: it takes seriously their experiences, knowledge and the contexts in which they live (Morkel 2012:63).

\section{Conclusion}

In this article we considered the building blocks for a theory of pastoral ministry through congregational life, as practical expression of a missional ecclesiology. Following the framework for practical theological research as provided by Osmer, the kernels of a theoretical position on missional ministry was sought through reflecting on the contributions of diverse disciplines such as pastoral care, Narrative Therapy, biblical hermeneutics and missional ecclesiology. The purpose of this reflection was to provide a framework for the development of ministry practices in a congregational setting, enabling the members of the church to deconstruct their life stories in view of growing insights in the stories of God, of the societies they live in and of one another. Through these discerning practices they are able to reconstruct their own realities as an ongoing reflection of their participation in God's mission to this world. Since the focus of this article was on enabling the church to understand herself and her practices from the perspective of God and his mission, the establishing of a practical theory for congregational life and witness, stood at the core of a missional ecclesiology.

This missional ecclesiology is particularly relevant to congregations in a suburban, white and middleclass context stemming from mainline denominations and living in the maelstrom of changes pertaining to a post-apartheid South Africa and the challenges these changes pose to the respective local communities.

\section{Acknowledgements Competing interests}

The author declares that he has no financial or personal relationships which may have inappropriately influenced him in writing this article.

\section{References}

Baker, M., 2011, Chart of James Fowler's stages of faith, viewed 02 January 2014, from http://www.usefulcharts.com/psychology/james-fowler-stages-of-faith.html

Berinyuu, A., 1988, Pastoral care to the sick in Africa: An approach to transcultura pastoral theology, Peter Lang, Frankfurt.

Bons-Storm, R., 1989, Hoe gaat het met jou? Pastoraat als komen tot verstaan, Kampen, Kok.

Bosch, D.J., 1991, Transforming mission, paradigm shifts in theology of mission, Orbis Books, New York.

Burger, C.W., 1999, Gemeentes in die Kragveld van die Gees, oor die unieke identiteit, taak en bediening van die kerk van Christus, Lux Verbi, Stellenbosch.

Burnham, J.B., 1986, Family therapy, Routledge, London. http://dx.doi org/10.4324/9780203404379

Caputo, J.D., 1997, The prayers and tears of Jacques Derrida: Religion without religion, Indiana University Press, Bloomington.
Cherry, K., 2012, What is emotional intelligence? Definitions, history, and measures of emotional intelligence, viewed 18 January 2014, from http://psychology.about. com/od/personality development/a/emotionalintell.htm

De Klerk, J.J., 1978, Herderkunde, NG Kerkboekhandel, Pretoria.

Egan, G., 1990, The skilled helper: A systematic approach to effective helping, 4th edn., Brooks/Cole, Pacific Grove.

Fowler, J., 1981, Stages of faith: The psychology of human development and the quest for meaning, Harper, San Francisco.

Franks, M., 1998, 'Election, pluralism and the missiology of Scripture in a postmodern age', Missiology, 26(329-343), 342.

Friel, J. \& Friel, L., 1990, An adult's guide to what's 'normal', Health Communications, Deerfield Beach.

Gehring, R.W., 2004, House church and mission: The importance of household structures in early Christianity, Hendrickson Publishers, Peabody.

Gibbs, E. \& Coffey, I., 2001, Church next: Quantum changes in Christian ministry, InterVarsity Press, Leicester.

Güder, D.L., 2000, The continuing conversion of the church, William. B. Eerdmans Publishing Company, Grand Rapids.

Hackman, J.R., 2002, Leading teams, setting the stage for great performances, Harvard Business School Press, Boston.

Hamman, J.J., 2005, When steeples cry: Leading congregations through loss and change, The Pilgrim Press, Cleveland.

Hanko, H., Hoeksema, H. \& Van Baren, G.J., 1976, The five points of Calvinism, Reformed Free Publishing, Grandville.

Harris, T.A., 1973, I'm OK-you're OK, PAN Books, London.

Hawkins, G.L. \& Parkinson, C., 2011, Move: What 1,000 churches reveal about spiritual growth, Kindle Edition, Zondervan, Grand Rapids.

Heitink, G., 1993, Praktische theologie, Kampen, Kok.

Hiltner, S., 1958, Preface to pastoral theology: The ministry and theology of shepherding, Abingdon Press, Nashville.

Keifert, P., 2007, Ons is nou hier: 'n Nuwe era van gestuur-wees, Wellington, Bybelmedia.

Kenney, G.C., 2000, Leadership in John: An analysis of the situation and strategy of the Gospel and the epistles of John, University Press of America, Oxford.

Kuhn, T., 1996, The structure of scientific revolutions, 3rd edn., University of Chicago Press, Chicago. http://dx.doi.org/10.7208/chicago/9780226458106.001.0001

Louw, D.J., 1994, Illness as crisis and challenge: Guidelines for pastoral care, Orion Publishers, Halfway House

Louw, D.J., 1999, Pastoraat as vertolking en ontmoeting: Teologiese ontwerp vir 'n basisteorie, antropologie, metode en terapie, Lux Verbi, Kaapstad.

Lyotard, J.F., 1984, The postmodern condition: A report on knowledge, Manchester University Press, Manchester.

Martoia, R., 2007, Static, tune out the 'Christian noise' and experience the real message of Jesus, Tyndale House Publishers, Carol Stream.

McKnight, S., 2008, The blue parakeet: Rethinking how you read the Bible, Zondervan, Grand Rapids.

Migliori, D.L., 2004, Faith seeking understanding: An introduction to Christian theology, 2nd edn., William B. Eerdmans Publishing Company, Grand Rapids.

Miller, M.R., 2004, The millennium matrix: Reclaiming the past, reframing the future of the church, Jossey Bass, San Francisco.

Morkel, E., 2012, Pastoral participation in transformation: A narrative perspective, D.Th. Dissertation (unpublished), Department of Theology, University of Stellenbosch.

Müller, J., 2011, Om te mag twyfel: 'n Gelowige se reis, Tafelberg Uitgewers, Cape Town.

National Association of Cognitive-Behavioral Therapists (NACBT), 2008, History of cognitive-behavioral therapy, viewed 18 January 2014, from http://nacbt.org/ historyofcbt.htm

Nel, M., 1994, Gemeentebou, Orion, Halfway House.

Nell, I.A., 2011, 'Practical theology as "healing of memories": Critical reflections on a specific methodology', HTS Teologiese Studies/ Theological Studies, 67(2), Art. \#1001, 8 pages. http://dx.doi.org/10.4102/hts.v67i2.1001

Niemandt, N., 2007, Nuwe drome vir nuwe werklikhede: Geloofsgemeenskappe in pas met' $n$ postmoderne wereld, Lux Verbi, Wellington.

O'Day, G., 1995, 'Toward a narrative-critical study of John', Interpretation 49(4), 341 346. http://dx.doi.org/10.1177/002096439504900402

Ortberg, J., 1997, The life you've always wanted: Spiritual disciplines for ordinary people, Zondervan, Grand Rapids.

Osmer, R.R., 1992, Teaching for faith: A guide for teachers of adult Classes, Westminster John Knox Press, Louisville.

Osmer, R.R., 2008, Practical theology: An introduction, William B. Eerdmans Publishing Company, Grand Rapids.

Payne, M., 2006, Narrative therapy: An introduction for counsellors, 2nd edn., SAGE Publications, London.

Ricoeur, P., 1991, From text to action: Essays in hermeneutics, Northwestern University Press, Evanston. 
Robinson, A.B. \& Wall, R.W., 2006, Called to be church: The book of Acts for today, William B. Eerdmans Publishing Company, Grand Rapids.

Scazzero, P. \& Bird, W., 2003, The emotionally healthy church: A strategy for discipleship that actually changes lives, Zondervan, Grand Rapids.

Smit, G., 1997, Ekklesiologie en gemeentebou: 'n Prakties-teologiese studie, DD Dissertation (unpublished), Department of Practical Theology, University of Pretoria.

Smit, D., 2006, Neem, lees! Hoe ons die Bybel hoor en verstaan, Lux Verbi, Wellington.

Smit, G., 2008, 'Die ontwikkeling van 'n strategiese gemeentelike ekklesiologie: Op pad na 'n missionerende bedieningspraxis', Acta Theologica 1, 161-175.

Smit, G., 2011, Marturia in the Gospel of John: A South African perspective on an emerging, missional ecclesiology, PhD Dissertation (unpublished), Department of New Testament Studies, University of Pretoria.

Smith, C. \& Snell, P., 2009, Souls in transition: The religious and spiritual lives of emerging adults, Oxford University Press, Oxford. http://dx.doi.org/10.1093/acpr of:oso/9780195371796.001.0001
Sweet, L., 1999, Soul Tsunami: Sink or swim in new millennium culture, Zondervan, Grand Rapids.

Sweet, L., 2004, Summoned to lead, Zondervan, Grand Rapids.

Turner, V.W., 1986, The anthropology of performance, PAJ Publications, New York.

Ursinus, Z., 1563, 'The Heidelberg Catechism', Christian Reformed Church Beliefs, viewed 31 January 2014, from http://www.crcna.org/pages/heidelberg_main.cfm

Van Huyssteen, W., 1987, Teologie as kritiese geloofsverantwoording, Human Sciences Research Council, Pretoria.

White, M. \& Epston, D., 1990, Narrative means to therapeutic ends, Norton \& Company, New York.

Willard, D., 2006, The great omission: Reclaiming Jesus' essential teachings on discipleship, Monarch Books, Oxford.

Wright, C.J.H., 2006, The mission of God: Unlocking the Bible's grand narrative, IVP Academic, Downer's Grove.

Wright, N.T., 2009, Justification - God's plan and Paul's vision, IVP Academic, Downer's Grove. 